\title{
Advances in hormone replacement therapy with drospirenone, a unique progestogen with aldosterone receptor antagonism
}

\author{
Santiago Palacios ${ }^{\mathrm{a}, *}$, Jean-Michel Foidart ${ }^{\mathrm{b}}$, Andrea R. Genazzani ${ }^{\mathrm{c}}$ \\ ${ }^{a}$ Instituto Palacios, Salud y Medicina de la Mujer, Madrid, Spain \\ ${ }^{\mathrm{b}}$ Department of Obstetrics, Gynecology and Senology at the University of Liege, Belgium \\ c Department of Obstetrics and Gynecology, University of Pisa, Italy
}

\begin{abstract}
Unlike other currently available progestogens, drospirenone (DRSP) has a pharmacological profile, which closely mimics that of endogenous progesterone, most notably potent anti-aldosterone and anti-androgenic effects. Consequently, DRSP, when combined with 17 $\beta$-estradiol (E2) as hormone replacement therapy (HRT), offsets E2-related water and sodium retention by blocking the mineralocorticoid receptor. This review evaluates the potential benefits offered by DRSP as the progestin component of HRT with respect to its anti-aldosterone activity, which translates into positive effects on body weight and blood pressure in clinical trials of continuous, combined E2/DRSP in post-menopausal women. In a 1 -year, large-scale, randomised, controlled trial, E2 1 mg/DRSP $2 \mathrm{mg}$ significantly decreased mean body weight by $1.2 \mathrm{~kg}$ versus baseline $(P<0.001)$, whereas patients receiving E2 $1 \mathrm{mg}$ gained weight. E2 $1 \mathrm{mg} / \mathrm{DRSP} 2 \mathrm{mg}$ also significantly lowered mean systolic blood pressure (SBP) by $9.0 \mathrm{mmHg}$ from baseline $(P<0.05)$ versus $3.7 \mathrm{mmHg}$ in the E2 $1 \mathrm{mg}$ group $(P=0.220)$ in a sub-group of hypertensive women. In addition, E2/DRSP was not associated with hyperkalemia (potassium $\geq 5.5$ $\mathrm{meq} / \mathrm{L}$ ) irrespective of concomitant use of ACE inhibitors, angiotensin II receptor antagonists or non-steroidal anti-inflammatory drugs, and co-morbid diabetes mellitus. In summary, as well as effectively treating climacteric symptoms, DRSP $2 \mathrm{mg}$ combined with E2 $1 \mathrm{mg}$ has shown positive effects on body weight and blood pressure in clinical trials, most likely due to DRSP's anti-aldosterone properties. This combination may therefore offer an alternative therapeutic option with additional benefits beyond current HRT agents for symptomatic postmenopausal women.
\end{abstract}

Keywords: Progestogen; Hormone replacement therapy; Drospirenone; Post-menopausal women; Hypertension

\section{Introduction}

It is estimated that 47 million women per annum will be menopausal by 2030 [1], and approximately $80 \%$ of these women will experience transient or permanent symptoms, related to the loss of estrogens, during the menopause stages [2]. The transient menopausal symptoms can be vasomotor in origin, i.e. hot flushes, night sweats or palpitations, or psychological, such as insomnia. Permanent symptoms include urogenital atrophy and osteoporosis.

For decades, estrogen, either alone or in combination with progestogens, has been the therapy of choice for the relief of menopausal symptoms, as well as for the long-term prevention of post-menopausal osteoporosis. The inclusion of a progestogen in continuous combined hormone replacement therapy (HRT) decreases the risks of endometrial hyperplasia and cancer associated with unopposed estrogen therapy, and this approach eliminates regular withdrawal bleeding $[3,4]$. Evidence-based guidelines strongly recommend the use of combined estrogen/progestin therapy in women with an intact uterus, using the lowest dose to relieve symptoms effectively and minimise side-effects [5-9]. However, the potential benefits of HRT on cardiovascular disease, blood pressure and weight gain remain controversial, and may depend on the specific regimen used.

Post-menopausal women have a higher prevalence of hypertension than pre-menopausal women [10-12], and are consequently at an increased risk of cardiovascular disease. High blood pressure is a modifiable risk factor, as reductions can lower the incidence of stroke and coronary heart disease (CHD). Even lowering the blood pressure in pre-hypertensive individuals (systolic blood pressure [SBP] 120-139 $\mathrm{mmHg}$ or diastolic blood pressure [DBP] 80-89 $\mathrm{mmHg}$ ) may have an added health benefit [13]. Treatment with conventional HRT appeared to have no significant effect on blood pressure in a number of studies [13-18]. The risk of hypertension was increased in current HRT users in the WHI study, although this may have been related in part to the older 
patient cohort in this study (average 62 years) [12]. In some patients, blood pressure may increase due to the water- and sodium-retaining effects of the estrogen in HRT preparations, mediated via the renin-angiotensinaldosterone system (RAAS) [19].

Weight changes can occur independently of the menopause, although adverse weight changes in body fat distribution and composition are linked to hormonal changes [20]. It is widely perceived that HRT causes weight gain $[21,22]$, although data from clinical trials examining weight gain is inconclusive, in some studies showing an increase in overall body weight [15,23-25] and others showing no significant effect [26-32]. It is possible that differences in measures of weight gain, physical activity of responders, HRT regimens (e.g. the use of micronized progesterone), may account for the differences observed in these trials. Some studies indicate that HRT may have positive effects on body fat distribution [25,28-32], for example, data from the Post-menopausal Estrogen/Progestin Interventions (PEPI) trial showed that HRT may reduce central adiposity [32], although the current evidence is inconclusive [26].

Nevertheless, weight gain is perceived as a side-effect and is commonly cited as a reason for not taking HRT $[21,22,33,34]$. The Norwegian Woman and Cancer (NOWAC) study, which sampled 4996 women (1024 HRT users that experienced side-effects were identified) aged $45-64$ years, showed that $56.3 \%$ of women experiencing troublesome side-effects reported weight gain as a side-effect [33]. Similar findings were observed in another large-scale survey of 816 women (449 responders). This study showed that concerns about weight gain were associated with a significant risk $(\mathrm{RR}=2.06)$ for discontinuing HRT [34]. In contrast to endogenous progesterone, the currently available synthetic progestogens lack anti-aldosterone activity. This may result in HRT-associated water retention and bloating as a consequence of estrogen activity on the RAAS, which could contribute to perceived weight gain. This highlights the need for progestogenic compounds that mimic the effects of endogenous progesterone on the RAAS. Drospirenone (DRSP) is a novel progestogen with aldosterone receptor antagonism (PARA). In contrast with most synthetic progestogens, DRSP displays a very similar pharmacological profile to endogenous progesterone [35-37]. Thus, DRSP exhibits anti-aldosterone and antiandrogenic properties, but is devoid of any estrogenic, glucocorticoid or anti-glucocorticoid activity [35,36,3840]. In particular, the anti-aldosterone activity of DRSP provides the potential for positive effects on body weight and also on blood pressure due to counterbalancing estrogen-related water retention when used in an HRT preparation. Several studies have demonstrated the safety and efficacy of the continuous combined HRT, 17 $\beta$-estradiol (E2) $1 \mathrm{mg}$ and DRSP $2 \mathrm{mg}$ (Angeliq ${ }^{\circledR}$, Scher-ing AG, Germany) for the treatment of climacteric symptoms and prevention of post-menopausal osteoporosis [41-43]. In this review, the function of the RAAS, and in particular the effects of estrogen and progesterone, on body weight and blood pressure are discussed. The potentially advantageous effects of E2 $1 \mathrm{mg} / \mathrm{DRSP} 2 \mathrm{mg}$ on body weight and blood pressure in post-menopausal women are also evaluated. Due to its unique potent anti-aldosterone activity, DRSP in combination with E2, could offer an alternative HRT with a favourable benefit/riskratio for post-menopausal women.

\section{The influence of estrogen and progesterone on the RAAS}

The RAAS plays a key role in the regulation of body fluids and blood pressure. If there is a sustained fall in blood pressure, the kidney releases renin, which converts angiotensinogen to angiotensin I (Fig. 1). This inactive peptide is subsequently converted by angiotensin-converting enzyme (ACE) to the pharmacologically active angiotensin II. Angiotensin II in turn stimulates aldosterone secretion, resulting in conservation of sodium and water, and elimination of potassium by the kidney [40,44]. In addition, angiotensin II is a potent vasoconstrictor, causing acute elevations in blood pressure. The most important function of the RAAS is to prevent excessive sodium loss and to regulate blood pressure. In addition, aldosterone may be implicated in the pathogenesis of renal and cardiovascular disease.

The female sex hormones, estrogen and progesterone are both known to influence the RAAS. Endogenous and orally administered estrogens promote the synthesis of angiotensinogen, leading to increased plasma aldosterone levels via the RAAS $[19,44]$. The net physiological effect of unopposed estrogen is increased sodium and water retention, and decreased potassium retention. In the natural menstrual cycle, progesterone counteracts the endogenous estrogen-induced stimulation of the RAAS by competing with aldosterone at the mineralocorticoid receptor [44]. Ideally, synthetic progestogens should be capable of fulfilling this role in women treated with exogenous estrogens. 
Fig. 1. Influence of estrogen and progesterone on the renin-angiotensin-aldosterone system.

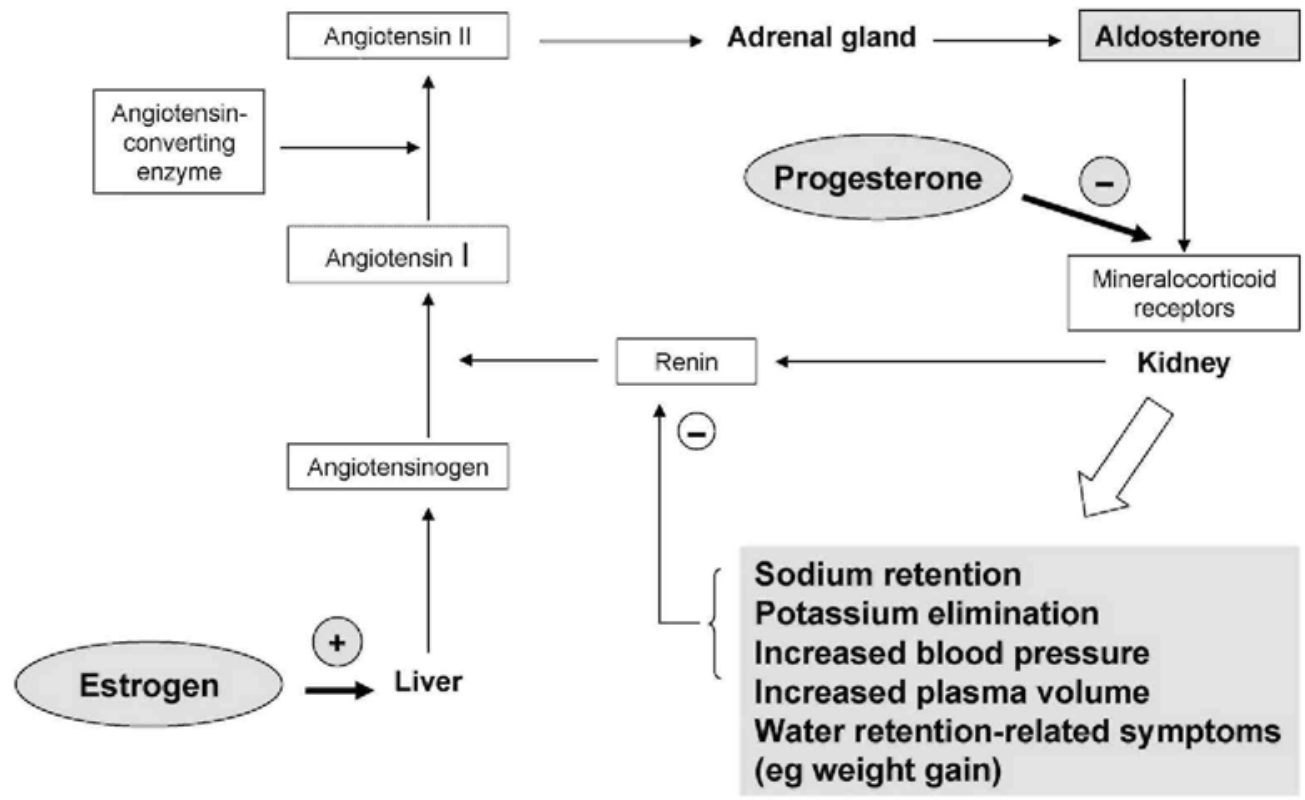

\section{DRSP: a synthetic progestogen with added benefits}

Progestogenic activity is essential in HRT preparations to counteract the proliferative effects of estrogen on the uterine endometrium. However, endogenous progesterone has low oral bioavailability and a short plasma halflife, rendering the hormone unsuitable for use in HRT preparations [45,46]. Although micronized progesterone is available for use in HRT, and data, for example, from the PEPI trial demonstrated that it is effective [18], most HRT combinations contain a synthetic progestogen, commonly derived from 19-nortestosterone (e.g. norethisterone acetate [NETA]) or 17 $\alpha$-hydroxyprogesterone (e.g. medroxyprogesterone acetate [MPA]) [46-48]. While all conventional progestogens exert progestogenic activity, they exhibit different patterns of binding at other steroid receptors and consequently display diverse biological activities (Table 1) [40,46-48], which also prevent meaningful extrapolation of the results for one progestogen to all progestogens as a class, or indeed to all HRT preparations.

Table 1: Comparison of the biological activities of progesterone and drospirenone with other progestogens

\begin{tabular}{|l|c|c|c|c|c|}
\hline \multicolumn{1}{|c|}{ Progestogens } & \multicolumn{5}{c|}{ Biological activities } \\
\hline & Progestogenic & Androgenic & Anti-androgenic & Anti-aldosterone & Glucocorticoid \\
\hline Progesterone & + & - & \pm & + & - \\
\hline Drospirenone & + & - & + & + & - \\
\hline Cyproterone acetate & + & - & + & - & \pm \\
\hline Dienogest & + & - & + & - & - \\
\hline Levonorgestrel & + & \pm & - & - & \pm \\
\hline $\begin{array}{l}\text { Medroxyprogesterone } \\
\text { acetate }\end{array}$ & + & \pm & - & - & - \\
\hline Norethisterone & + & \pm & - & \pm & - \\
\hline Trimegestone & + & - & \pm & - & - \\
\hline Norgestimate & + & \pm & - & - & - \\
\hline
\end{tabular}

Clinically relevant activity $(+)$; activity not clinically relevant $( \pm)$; no activity $(-)$. 
None of the progestogens currently used in conventional HRT preparations has a similar pharmacologic profile to that of progesterone, most notably with regard to their lack of anti-mineralocorticoid activity (Table 1). They are, therefore, unable to adequately counterbalance the water- and sodium-retaining effects of the estrogenic component of combined HRT, which may contribute to increased blood pressure and weight gain in susceptible individuals. As such, there is clearly an unmet clinical need for new, well-tolerated progestogenic compounds with improved selectivitythat mimic the effects of endogenous progesterone [47].

DRSP $(6 \beta, 7 \beta, 15 \beta, 16 \beta$-dimethylene-3-oxo-17 $\alpha$-pregn-4-ene-21,17-carbolactone), differs from conventional progestogens as it is derived from $17 \alpha$-spironolactone, rather than progesterone, 19-nortestosterone or 19norprogesterone [46,47]. The novel chemical structure of DRSP underpins its unique receptor binding profile among synthetic progestogens. Moreover, its binding region and biological activities are closely akin to those of endogenous progesterone (Table 1) $[35,36,40]$. DRSP and progesterone both exhibit moderate binding affinity to progesterone receptors and high binding affinity to mineralocorticoid receptors (as antagonists) in the uterus and kidney [45]. Both DRSP and progesterone have considerable anti-mineralocorticoid activity in transactivation studies of hormone receptors [35,38]. The anti-androgenic potency of DRSP is reported to be 5-10 times greater than that of progesterone and one-third that of cyproterone acetate (CPA). This contrasts with the absence of anti-androgenic activity for MPA [40,45]. Neither DRSP nor natural progesterone display estrogenic, androgenic or glucocorticoid activity $[44,45,47]$. Unlike other progestogens, DRSP has anti-aldosterone activity. The binding affinity of DRSP at the mineralocorticoid receptor is 2.3- to 5-fold higher than that of aldosterone, whereas the affinity of MPA or NETA is only approximately 3\% that of aldosterone, and neither display antimineralocorticoid activity $[45,47]$. In spontaneously hypertensive rats, SBP and DBP were decreased or remained unchanged over 27 days of DRSP administration, whereas blood pressure increased with conventional progestogens, such as CPA [45]. In addition, DRSP has been shown to increase sodium excretion compared with placebo or CPA in menstruating women [44]. Like progesterone, DRSP therefore has the potential to counter the increase in sodium and water retention caused by estrogenic stimulation of the RAAS, which may otherwise result in increased plasma volume, water retention-related symptoms and raised blood pressure in susceptible individuals. Thus, in contrast with conventional progestogens, the unique PARA activity of DRSP may offer beneficial effects on blood pressure and body weight in post-menopausal women. The ratio of pro-gestogenic to anti-mineralocorticoid activity is similar for DRSP and progesterone [44], and DRSP is the only available progestogen that has significant anti-aldosterone activity at dose levels sufficient to oppose the effects of E2 on the endometrium. DRSP in combination with E2 has, therefore, been developed as a continuous combined HRT, as well as an oral contraceptive with ethinyl estradiol (EE).

\section{The effect of DRSP on blood pressure}

Hypertension, defined by the JNC VII guidelines [13] as stage 1: SBP 140-159 mmHg or DBP 90-99 mmHg; stage 2: $\mathrm{SBP} \geq 160 \mathrm{mmHg}$ or DBP $\geq 100 \mathrm{mmHg}$, is linked to cardiovascular disease [49-51], a leading cause of death in the western world [52]. In the Framingham Heart Study, a longitudinal 30-year survey, which examined data from normotensive and untreated hypertensive subjects, SBP increased linearly with age; if left untreated, elevated SBP can accelerate large artery stiffness, an independent determinant of cardiovascular risk [51].

Age-related conditions such as the menopause can also have an impact on blood pressure. In a random crosssectional survey of households where blood pressure was measured on-site, data from 278 premenopausal women and 184 post-menopausal women showed that the latter group was associated with a higher incidence of hypertension ( $\geq 140 / 90 \mathrm{mmHg}$ ), which was still evident after adjusting for age and body mass index (BMI) [10]. Although blood pressure measurements were home-based, these results may still be subject to the white-coat effect, which is more relevant in small samples. Another larger survey, which reviewed 15 longitudinal and cross-sectional studies, found that after adjusting for age and BMI, no significant correlation was found between menopause and blood pressure. However, this paper did not state whether these subjects were normotensive or hypertensive at baseline, or whether they were receiving HRT or anti-hypertensive therapy [53].

The link between post-menopausal estrogen deficiency, hypertension and subsequent risk of cardiovascular disease, therefore, remains somewhat unclear. A review of blood pressure changes in hypertensive postmenopausal women receiving conventional HRT agents has revealed a variety of effects, although in general, risks of increased blood pressure during therapy were low [13-18,53]. A small, observational study of 226 normotensive post-menopausal women showed that HRT users had a smaller increase in SBP than non-users over the 5-6 year follow-up (change in SBP: $8.9 \mathrm{mmHg}$ versus $1.6 \mathrm{mmHg} ; P=0.01$ ) [17]. However, one cannot rule out the possibility of a natural ageing effect, such as that observed in the Framingham Heart Study [51], 
given the absence of a control group or defined endpoints. A number of well-designed trials (see Table 2) have consistently demonstrated a significant blood pressure-lowering effect with DRSP plus E2 in postmenopausal women [43,54-56]. This is consistent with the potent anti-aldosterone activity of DRSP. In one study, 24 postmenopausal hypertensive women treated with enalapril (baseline blood pressure: 139/82 $\mathrm{mmHg}$ ) were randomised to treatment with E2 $1 \mathrm{mg} / \mathrm{DRSP} 3 \mathrm{mg}$ once daily or placebo plus enalapril for 14 days. Blood pressure was measured by $24 \mathrm{~h}$ ambulatory monitoring. E2/DRSP significantly reduced $24 \mathrm{~h}$ mean $( \pm$ S.E. $)$ SBP by $9 \mathrm{mmHg}( \pm 1.4)$ and DBP by $5 \mathrm{mmHg}( \pm 1.2)$ from baseline (both $P<0.05)$, whereas no change in blood pressure was observed in the placebo plus enalapril group [54]. These findings show that E2/DRSP has added benefits on blood pressure when used in combination with other anti-hypertensive agents.

Table 2: Summary of trials demonstrating the blood pressure-lowering effects of DRSP

\begin{tabular}{|c|c|c|c|c|}
\hline Study & Population & Design & BP definition(s) & Outcomes \\
\hline $\begin{array}{l}\text { Preston et al. } \\
{[54]}\end{array}$ & $\begin{array}{l}\text { Post-menopausal } \\
\text { women }(n=24) \\
\text { treated with } \\
\text { E2/DRSP/ENA or } \\
\text { PLA/ENA }\end{array}$ & $\begin{array}{l}\text { 14-day, double-blind, } \\
\text { PLA-controlled, } \\
\text { randomised, parallel- } \\
\text { group study }\end{array}$ & $\begin{array}{l}24 \mathrm{~h} \text { ambulatory BP } \\
\text { (no HTN criteria } \\
\text { used) }\end{array}$ & $\begin{array}{l}\text { Significant additive BP- } \\
\text { lowering effect of } \\
\text { E2/DRSP (mean decrease } \\
\text { from } 139 / 80 \text { to } 130 / 75 \\
\text { mmHg), consistent with } \\
\text { anti-mineralocorticoid } \\
\text { effect }\end{array}$ \\
\hline $\begin{array}{l}\text { Preston et al. } \\
{[55]}\end{array}$ & $\begin{array}{l}\text { Post-menopausal } \\
\text { women with T2D } \\
(n=82) \text { or without } \\
\text { T2D }(n=148) \text { treated } \\
\text { with E2/DRSP or } \\
\text { PLA }\end{array}$ & $\begin{array}{l}\text { 28-day, randomised, } \\
\text { PLA-controlled, } \\
\text { multicentre study }\end{array}$ & $\begin{array}{l}\text { Changes in clinic BP } \\
\text { (no definition of HTN } \\
\text { but baseline BP was } \\
132 / 81 \mathrm{mmHg} \text { ) }\end{array}$ & $\begin{array}{l}\text { Higher BP reductions for } \\
\text { E2/DRSP than PLA (mean } \\
\text { reduction in total group: } \\
-8.6 /-5.8 \text { to }-3.7 /-2.9 \\
\text { mmHg; } P<0.01) \text {. No } \\
\text { difference in hyperkalemia } \\
(K \geq 5.5 \text { meq/L) between } \\
\text { treatment groups }\end{array}$ \\
\hline $\begin{array}{l}\text { White et al. } \\
{[56]}\end{array}$ & $\begin{array}{l}\text { Post-menopausal } \\
\text { women with stage } 1 \\
\text { HTN }(n=213) \\
\text { treated with } \\
\text { E2/DRSP or PLA }\end{array}$ & $\begin{array}{l}\text { 12-week, multicentre, } \\
\text { double-blind, } \\
\text { randomised, PLA- } \\
\text { controlled }\end{array}$ & $\begin{array}{l}\text { Stage } 1 \text { HTN defined } \\
\text { as SBP 140-159 } \\
\text { and/or DBP 90-99 } \\
\text { mmHg. Endpoints } \\
\text { were changes in clinic } \\
\text { BP and } 24 \mathrm{~h} \\
\text { ambulatory BP }\end{array}$ & $\begin{array}{l}\text { Mean clinic BP reductions } \\
\text { for E2/DRSP vs. PLA were } \\
-14.1 /-7.9 \text { and-7.1/-4.3 } \\
\text { mmHg }(P<0.0001) \text {. } \\
\text { Significant reductions in } \\
\text { mean } 24 \text { h SBP were also } \\
\text { observed after treatment } \\
\text { with E2/DRSP }(P=0.002)\end{array}$ \\
\hline $\begin{array}{l}\text { Archer et al. } \\
{[43]}\end{array}$ & $\begin{array}{l}\text { Post-menopausal } \\
\text { women } \\
(n=1147) \text { treated } \\
\text { with } \\
\text { continuous } \\
\text { E2 with/without } \\
\text { DRSP (5 } \\
\text { regimens in total) }\end{array}$ & $\begin{array}{l}\text { Multicentre, double- } \\
\text { blind, randomised, } \\
\text { parallel-group study } \\
(13,28 \text {-day treatment } \\
\text { cycles })\end{array}$ & $\begin{array}{l}\text { Endometrial } \\
\text { hyperplasia (primary } \\
\text { endpoint); BP } \\
\text { (secondary endpoint) }\end{array}$ & $\begin{array}{l}\text { The probability of } \\
\text { hyperplasia was } 0.060 \text { for } \\
\text { the E2 group compared } \\
\text { with } 0.007 \text { for E2/DRSP } \\
2 \mathrm{mg} \text {. Significant reduction } \\
\text { in mean BP after treatment } \\
\text { with E2/DRSP } 2 \mathrm{mg} \text { vs. E2 } \\
(-9.0 /-5.7 \mathrm{mmHg} \text { vs. }-3.7 / \\
-2.7 \mathrm{mmHg})\end{array}$ \\
\hline
\end{tabular}

In a larger study, 230 post-menopausal hypertensive women treated with anti-hypertensive therapy (baseline blood pressure: 132/80 mmHg) were randomised to treatment with E2 $1 \mathrm{mg} / \mathrm{DRSP} 3 \mathrm{mg}$ or placebo for 28 days [55]. The mean decrease in clinic SBP from baseline was greater for E2/DRSP than placebo (-9.62 \pm 1.30 and $2.78 \pm 1.02 \mathrm{mmHg}$, respectively; $P<0.001)$ (Fig. 2A). Corresponding values for DBP were $-5.74 \mathrm{mmHg}( \pm 0.72)$ and $-2.94 \mathrm{mmHg}( \pm 0.65)$, respectively $(P<0.01)$ (Fig. 2B). A similar trend was observed in a sub-group of patients with type 2 diabetes mellitus.

In post-menopausal women with untreated stage 1 hypertension (SBP 140-159 mmHg; DBP 90-99 mmHg), treatment with E2 $1 \mathrm{mg} / \mathrm{DRSP} 3 \mathrm{mg}$ decreased both clinic and $24 \mathrm{~h}$ ambulatory blood pressure compared with 
placebo after 12 weeks of therapy [56]. The mean clinic blood pressure was decreased by $14.1 / 7.9 \mathrm{mmHg}$ (SBP/DBP) from baseline in patients receiving E2/DRSP compared with only 7.1/4.3 $\mathrm{mmHg}$ in the placebo group $(P<0.0001)$. These findings show that the combination of E2 $1 \mathrm{mg} / \mathrm{DRSP} 3 \mathrm{mg}$ has a significant effect on blood pressure in untreated hypertensive patients and an additive effect in patients treated with antihypertensives. The reductions observed in the placebo group of these trials are consistent with previous findings and were not due to any lifestyle interventions. The placebo effect is a well-recognised phenomenon in blood pressure trials, and is usually more evident with clinic measures than $24 \mathrm{~h}$ ambulatory monitoring [57]. In a longterm trial, which evaluated the safety of E2 $1 \mathrm{mg}$ and four regimens of E2 $1 \mathrm{mg} / \mathrm{DRSP}(0.5,1,2 \mathrm{or} 3 \mathrm{mg})$ in 1147 post-menopausal women, the combination of E2/DRSP was effective in protecting against endometrial hyperplasia [43]. Secondary endpoints included, amongst others, blood pressure assessments. Based on a post hoc analysis in 102 hypertensive women ( $\mathrm{SBP} \geq 140 \mathrm{mmHg}$ and/or DBP $\geq 90 \mathrm{mmHg}$ ), there was a significant decrease in mean SBP from baseline in those receiving E2 $1 \mathrm{mg} / \mathrm{DRSP} 2 \mathrm{mg}(-9.0 \mathrm{mmHg} ; P=0.011 ; n=15)$ whereas the decrease from baseline was not significant with E2 monotherapy $(-3.7 \mathrm{mmHg} ; P=0.220 ; n=15)$ after 13, 28-day treatment cycles. Similarly, the mean DBP change from baseline in the E2/DRSP group was -5.7 $\mathrm{mmHg}(P<0.001)$ compared with $-2.7 \mathrm{mmHg}$ in the E2 monotherapy group $(P=0.108)$, although intertreatment comparisons did not reach significance. While this study also demonstrated a beneficial effect of E2/DRSP on total cholesterol and low-density lipoprotein cholesterol, there was no actual assessment of cardiovascular endpoints such as stroke, CHD or myocardial infarction. Long-term studies are needed to address the effect of E2/DRSP on cardiovascular outcomes in order to determine whether the observed reduction of blood pressure has implications for these serious risks.

Fig. 2. Mean ( \pm S.E.) $S B P(A)$ and $D B P(B)$ in post-menopausal women receiving treatment with E2 $1 \mathrm{mg} / D R S P$ $3 \mathrm{mg}$ or placebo for 28 days. DBP, diastolic blood pressure; DRSP, drospirenone; E2, 17 $\beta$-estradiol; SBP, systolic blood pressure [55].
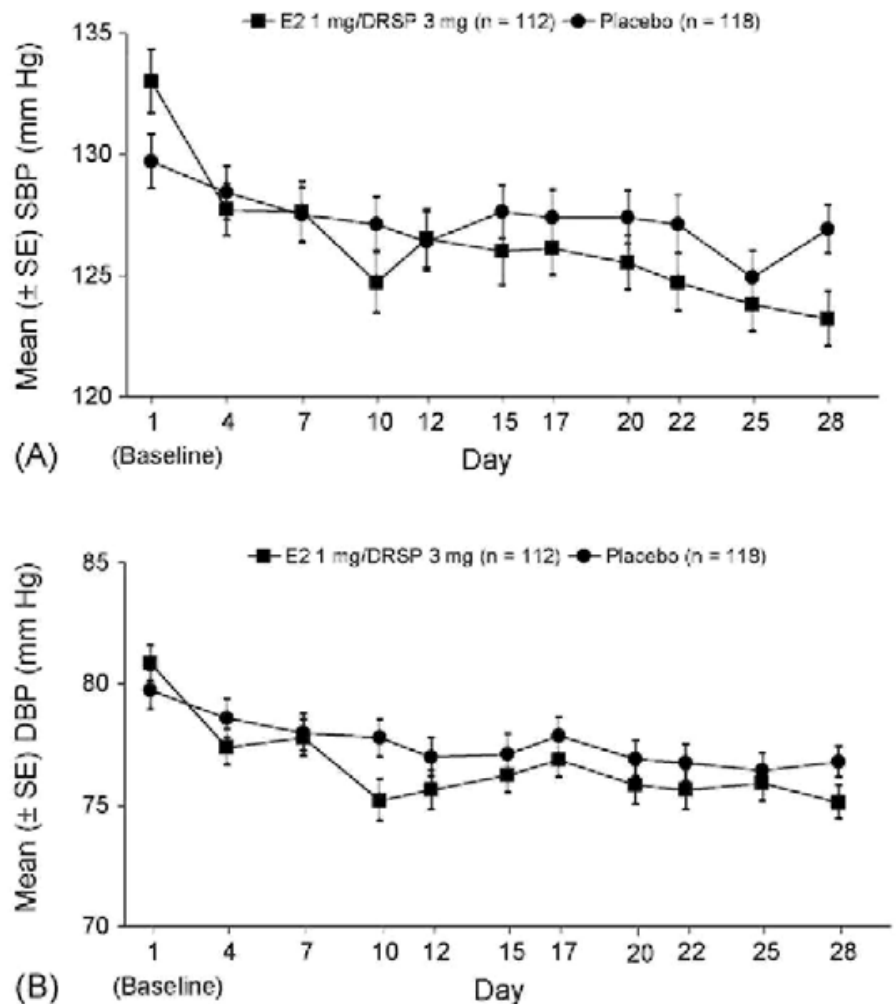

Nevertheless, these findings show that E2/DRSP consistently lowers blood pressure, which is most likely related to the anti-aldosterone activity of DRSP; aldosterone blockade increases renal sodium excretion, potentially leading to a reduction in SBP and DBP. Concomitant with the increase in sodium excretion via the RAAS, aldosterone receptor antagonists may also increase serum potassium concentrations, particularly in susceptible individuals [19,37]. However, E2/DRSP has not been associated with hyperkalemia (potassium $\geq 5.5$ meq/L), even in high-risk patients $[43,55,56]$. When compared with placebo, treatment with E2 $1 \mathrm{mg} / \mathrm{DRSP} 3 \mathrm{mg}$ did not 
increase serum potassium concentrations or the incidence of hyperkalaemia, irrespective of concomitant use of ACE inhibitors, angiotensin II receptors antagonists or nonsteroidal anti-inflammatory drugs, and co-morbid diabetes mellitus [55]. In addition, there were no clinically or statistically significant changes in serum potassium concentrations in patients with mild renal impairment and normal renal function when treated with DRSP or placebo [55].

Overall, E2 $1 \mathrm{mg} / \mathrm{DRSP} 2$ or $3 \mathrm{mg}$ lowered SBP by approximately 7-14 mmHg and DBP by approximately 5-8 $\mathrm{mmHg}$ in hypertensive post-menopausal women in these trials. Although these changes may appear small, decreases in SBP of only 2-3 mmHg have previously been associated with improved cardiovascular outcomes [58-60]. Mean reductions in SBP and DBP of 10 and $4 \mathrm{mmHg}$, respectively, have been shown to decrease the risks of stroke and myocardial infarction by $30 \%$ and $23 \%$ [58]. There is also evidence to suggest that across the blood pressure range 115/75-185/115 $\mathrm{mmHg}$, the risk of cardiovascular disease doubles with each increment of $20 / 10 \mathrm{mmHg}$ in individuals aged 40-70 years [61]. These findings underscore the importance of even small decreases in blood pressure, and concur with recommendations to lower blood pressure by lifestyle changes even in pre-hypertensive individuals (i.e. SBP $120-139 \mathrm{mmHg}$ or DBP $80-89 \mathrm{mmHg}$ ), as they are twice as likely to develop hypertension than individuals with lower blood pressures [13]. As yet, however, there are no data indicating that E2 $1 \mathrm{mg} / \mathrm{DRSP} 2 \mathrm{mg}$ has a role in reducing the risk of stroke or CHD in post-menopausal women with elevated blood pressure.

\section{The effect of DRSP on body weight}

Although women tend to gain weight after the menopause, regardless of whether or not they are prescribed HRT, particular concern among patients about weight gain during HRT can deter initiation of treatment and cause poor compliance and/or early discontinuation among users [21,22,33,34]. For instance, one quarter of former HRT users aged 45-75 years cited weight gain as a reason to discontinue therapy in a European study of 8012 women [22].

As mentioned above, DRSP is a potent aldosterone antagonist that acts on the mineralocorticoid receptor to decrease sodium reabsorption and water retention. The potential benefits offered by this improved pharmacological profile of DRSP have translated into a positive effect on body weight in clinical trials of an oral contraceptive containing DRSP and EE [62-64] (see Table 3). Data from two large, randomised, comparative trials show that mean body weight remained significantly lower in women receiving the oral contraceptive EE 30 $\mu \mathrm{g} / \mathrm{DRSP} 3 \mathrm{mg}$ than in women receiving EE $30 \mu \mathrm{g} / \mathrm{desogestrel} 150 \mu \mathrm{g}$ over 13 or 26 cycles [63,64].

Similar findings have been shown when E2/DRSP is used as HRT in post-menopausal women [43]. In one trial (see Table 2), post-menopausal women receiving E2 $1 \mathrm{mg} / \mathrm{DRSP} 2 \mathrm{mg}$ experienced a small decrease in body weight, whereas women receiving E2 $1 \mathrm{mg}$ monotherapy tended to gain weight, even after the first treatment cycle (Fig. 3) [43]. At study end (cycle 13), the mean difference between treatments was $0.9 \mathrm{~kg}(\mathrm{P}<0.001)$, with women in the E2/DRSP group losing a mean of $1.2 \mathrm{~kg}$ versus baseline over the study period $(P<0.001)$. These results suggest that DRSP $2 \mathrm{mg}$, when used in a combined continuous HRT treatment with E2, has a body weight-lowering effect in post-menopausal women. This favourable effect likely reflects the unique ability of DRSP to counteract estrogen-related water and sodium retention, whereas conventional progestogens are devoid of such anti-mineralocorticoid activity.

Fig. 3. Change in body weight (mean \pm S.E.) in post-menopausal women receiving HRT with E2 $1 \mathrm{mg} / \mathrm{DRSP} 2 \mathrm{mg}$ or E2 $1 \mathrm{mg}$ for 13 cycles. ${ }^{*} P<0.001$ vs. E2 monotherapy. DRSP, drospirenone; E2, 17 $\beta$-estradiol; HRT, hormone replacement therapy; $S B P$, systolic blood pressure [43].

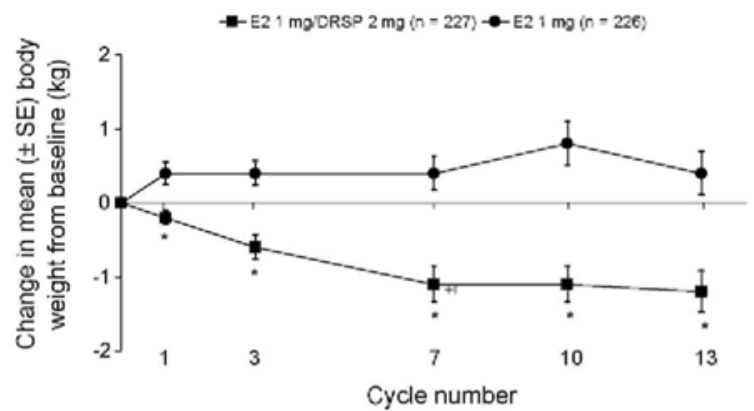


Table 3: Summary of trials showing the beneficial effects of DSP on weight

\begin{tabular}{|c|c|c|c|c|}
\hline Study & Population & Design & Weight assessment & Outcomes \\
\hline $\begin{array}{l}\text { Oelkers et al. } \\
{[62]}\end{array}$ & $\begin{array}{l}\text { Healthy women } \\
(n=80), \text { aged } 18-34 \\
\text { years, treated with } \\
\text { EE/DRSP or } \\
\text { levonorgestrel } \\
\text { (control) }\end{array}$ & $\begin{array}{l}\text { 6-month, randomised } \\
\text { trial ( } 6 \text { treatment } \\
\text { cycles })\end{array}$ & $\begin{array}{l}\text { Body weight } \\
\text { measured by women } \\
\text { on home scales every } \\
\text { second day } \\
\text { (unclothed, fasting } \\
\text { states). Mean weights } \\
\text { during a cycle were } \\
\text { used for calculations }\end{array}$ & $\begin{array}{l}\text { Body weight reductions } \\
\text { ranging from } 0.8 \text { to } 1.7 \mathrm{~kg} \\
\text { in the DRSP/EE groups } \\
\text { compared with an increase } \\
\text { in the control group of } 0.7 \\
\mathrm{~kg}(P<0.05 ; \mathrm{DRSP} / \mathrm{EE} \\
\text { groups vs. control) }\end{array}$ \\
\hline $\begin{array}{l}\text { Foidart et al. } \\
{[63]}\end{array}$ & $\begin{array}{l}\text { Healthy women }(n= \\
900), \text { aged } 18-35 \\
\text { years, treated with } \\
\text { EE/DRSP or } \\
\text { EE/desogestrel }\end{array}$ & $\begin{array}{l}\text { Randomised, open- } \\
\text { label, multicentre } \\
\text { study (26 treatment } \\
\text { cycles; 3-month } \\
\text { follow-up) }\end{array}$ & $\begin{array}{l}\text { Body weight } \\
\text { measured by women } \\
\text { on home scales } \\
\text { (unclothed, fasting } \\
\text { states). Weight } \\
\text { checked weekly. } \\
\text { Mean weights during } \\
\text { a cycle were used for } \\
\text { calculations. Mean } \\
\text { pre-treatment weight } \\
\text { was baseline }\end{array}$ & $\begin{array}{l}\text { In the DRSP/EE group, the } \\
\text { mean body weight } \\
\text { remained below baseline } \\
(-0.11 \text { to }-0.68 \mathrm{~kg}) . \text { In the } \\
\text { EE/desogestrel group, } \\
\text { there was an increase after } \\
\text { cycle } 5 \text { (range: }+0.02 \text { to } \\
+0.89 \mathrm{~kg})\end{array}$ \\
\hline $\begin{array}{l}\text { Huber et al. } \\
{[64]}\end{array}$ & $\begin{array}{l}\text { Healthy women } \\
(n=2069), \text { aged } 18- \\
35 \\
\text { years, treated with } \\
\text { EE/DRSP or } \\
\text { EE/desogestrel }\end{array}$ & $\begin{array}{l}\text { Randomised, open- } \\
\text { label, multicentre } \\
\text { study (13 treatment } \\
\text { cycles) }\end{array}$ & $\begin{array}{l}\text { Body weight } \\
\text { measured by women } \\
\text { on home scales } \\
\text { (unclothed, fasting } \\
\text { states). Mean weights } \\
\text { during a cycle were } \\
\text { used for calculations }\end{array}$ & $\begin{array}{l}\text { Weight loss was } \\
\text { significantly greater in the } \\
\text { EE/DRSP group than } \\
\text { EE/desogestrel }(-0.46 \mathrm{vs} \text {. } \\
-0.19 \mathrm{~kg} ; P<0.0072)\end{array}$ \\
\hline
\end{tabular}

\section{Conclusions}

DRSP has a pharmacodynamic profile that is more similar to that of endogenous progesterone than other currently available synthetic progestogens. When administered with E2 $1 \mathrm{mg}$, DRSP $2 \mathrm{mg}$ is an effective and well-tolerated HRT for the treatment of climacteric symptoms and prevention of post-menopausal osteoporosis. Due to the unique anti-aldosterone activity of DRSP, E2 $1 \mathrm{mg} / \mathrm{DRSP} 2 \mathrm{mg}$ also confers a positive effect on body weight and blood pressure in post-menopausal women. By avoiding estrogen-related side-effects such as bloating and weight gain, E2 $1 \mathrm{mg} / \mathrm{DRSP} 2 \mathrm{mg}$ may improve compliance with HRT, which is important in order to achieve maximum treatment benefits such as effective symptom relief and protection against osteoporosis. In addition, by reducing blood pressure in post-menopausal women, E2 $1 \mathrm{mg} / \mathrm{DRSP} 2 \mathrm{mg}$ may offer additional health benefits to women potentially at risk of later cardiovascular disease, although this has yet to be directly evaluated in clinical trials. In summary, the novel properties of DRSP, in combination with E2, provide an alternative therapeutic option with additional benefits beyond current HRT agents.

\section{Acknowledgement}

This work was supported by Schering AG.

\section{References}

[1] Hill K. The demography of menopause. Maturitas 1996;23:113-27.

[2] Consensus conference on hormone replacement therapy, October 2003. Final consensus statement. Royal College of Physicians of Edinburgh. Available at http://www.rcpe.ac.uk/ education/standards/consensus/hrt_03.php [Accessed 6 July 2006]. 
Published in: Maturitas (2006), vol. 55, iss.4, pp. 297-307

Status: Postprint (Author's version)

oestrogen-progestagen replacement therapy? UK Continuous Combined HRT Study Investigators. Lancet 1994;344: 979-82.

[4] Gambrell Jr RD, Massey FM, Castaneda TA, et al. Use of the progestogen challenge test to reduce the risk of endometrial cancer. Obstet Gynecol 1980;55:732-8.

[5] Position Statement by the Executive Committee of the International Menopause Society. Guidelines for hormone treatment of women in the menopausal transition and beyond. Maturitas 2005;51:15-20.

[6] National Institutes of Health. National Institutes of Health State-of-the-Science Conference statement: management of menopause-related symptoms. Ann Intern Med 2005;142: 1003-13.

[7] Skouby SO, Al-Azzawi F, Barlow D, et al. Climacteric medicine: European Menopause and Andropause Society (EMAS) 2004/2005 position statements on peri- and postmenopausal hormone replacement therapy. Maturitas 2005;51: 8-14.

[8] North American Menopause Society. Recommendations for estrogen and progestogen use in peri- and postmenopausal women: October 2004 position statement of The North American Menopause Society. Menopause 2004;11:589-600.

[9] Royal College of Obstetricians and Gynaecologists. Menopause and Hormone Replacement—study group recommendation. Consensus views arising from the 47th Study Group: Menopause and Hormone Replacement. Available at http:// www.rcog.org.uk/index.asp?PageID=310 [Accessed 6 July 2006].

[10] Staessen J, Bulpitt CJ, Fagard R, et al. The influence of menopause on blood pressure. J Hum Hypertens 1989;3:427-33.

[11] Rosenthal T, Oparil S. Hypertension in women. J Hum Hypertens 2000;14:691-704

[12] Wassertheil-Smoller S, Anderson G, Psaty BM, et al. Hypertension and its treatment in postmenopausal women: baseline data from the Women's Health Initiative. Hypertension 2000;36:780-9.

[13] Chobanian AV, Bakris GL, Black HR, et al. Seventh report of the Joint National Committee on Prevention, Detection, Evaluation, and Treatment of High Blood Pressure. Hypertension 2003;42:1206-52.

[14] Ichikawa J, Sumino H, Ichikawa S, Ozaki M. Different effects of transdermal and oral hormone replacement therapy on the reninangiotensin system, plasma bradykinin level, and blood pressure of normotensive postmenopausal women. Am J Hypertens 2006;19:744-9.

[15] Karalis I, Beevers G, Beevers M, Lip GYH. Hormone replacement therapy and arterial blood pressure in postmenopausal women with hypertension. Blood Press 2005;14:38-44.

[16] Manson JE, Hsia J, Johnson KC, et al. Estrogen plus progestin and the risk of coronary heart disease. N Engl J Med 2003;349:523-34.

[17] Scuteri A, Bos AJ, Brant LJ, et al. Hormone replacement therapy and longitudinal changes in blood pressure in postmenopausal women. Ann Intern Med 2001;135:229-38.

[18] The Writing Group for the PEPI Trial. Effects of estrogen or estrogen/progestin regimens on heart disease risk factors in postmenopausal women. The Postmenopausal Estrogen/Progestin Interventions (PEPI) Trial. JAMA 1995; 273:199-208.

[19] Oelkers WK. Effects of estrogens and progestogens on the renin-aldosterone system and blood pressure. Steroids 1996;61:166-71.

[20] Simkin-Silverman LR, Wing RR. Weight gain during menopause. Is it inevitable or can it be prevented? Postgrad Med 2000;108:47-56.

[21] Van Seumeren I. Weight gain and hormone replacement therapy: are women's fears justified? Maturitas 2000;34(Suppl. 1):S3-8.

[22] Strothmann A, Schneider HP. Hormone therapy: the European women's perspective. Climacteric 2003;6:337-46.

[23] Lip GY, Beevers M, Churchill D, Beevers DG. Hormone replacement therapy and blood pressure in hypertensive women. J Hum Hypertens 1994;8:491-4.

[24] Aloia JF, Vaswani A, Russo L, Sheehan M, Flaster E. The influence of menopause and hormonal replacement therapy on body cell mass and body fat mass. Am J Obstet Gynecol 1995;172:896-900.

[25] Arabi A, Garnero P, Porcher R, Pelissier C, Benhamou CL, Roux C. Changes in body composition during post-menopausal hormone therapy: a 2 year prospective study. Hum Reprod 2003;18:1747-52.

[26] Norman RJ, Flight IH, Rees MC. Oestrogen and progestogen hormone replacement therapy for perimenopausal and postmenopausal women: weight and body fat distribution. Cochrane Database Syst Rev 2000;2. CD001018.

[27] Utian WH, Gass ML, Pickar JH. Body mass index does not influence response to treatment, nor does body weight change with lower doses of conjugated estrogens and medroxyprogesterone acetate in early postmenopausal women. Menopause 2004;11:306-14. 
Published in: Maturitas (2006), vol. 55, iss.4, pp. 297-307

Status: Postprint (Author's version)

[28] Gambacciani M, Ciaponi M, Cappagli B, Genazzani AR. Effects of low-dose continuous combined conjugated estrogens and medroxyprogesterone acetate on menopausal symptoms, body weight, bone density, and metabolism in postmenopausal women. Am J Obstet Gynecol 2001;185:1180-5.

[29] Sorensen MB, Rosenfalck AM, Hojgaard L, Ottesen B. Obesity and sarcopenia after menopause are reversed by sex hormone replacement therapy. Obes Res 2001;9:622-6.

[30] Perrone G, Liu Y, Capri O, et al. Evaluation of the body composition and fat distribution in long-term users of hormone replacement therapy. Gynecol Obstet Invest 1999;48: 52-5.

[31] Kritz-Silverstein D, Barrett-Connor E. Long-term postmenopausal hormone use, obesity, and fat distribution in older women. JAMA $1996 ; 275: 46-9$

[32] Espeland MA, Stefanick ML, Kritz-Silverstein D, et al. Effect of postmenopausal hormone therapy on body weight and waist and hip girths. Postmenopausal Estrogen-Progestin Interventions Study Investigators. J Clin Endocrinol Metab 1997;82: 1549-56.

[33] Bakken K, Eggen AE, Lund E. Side-effects of hormone replacement therapy and influence on pattern of use among women aged 45-64 years. The Norwegian Women and Cancer (NOWAC) study. Acta Obstet Gynecol Scand 2004;83: 850-6.

[34] Reynolds RF, Obermeyer CM, Walker AM, Guilbert D. The role of treatment intentions and concerns about side effects in women's decision to discontinue postmenopausal hormone therapy. Maturitas 2002;43:183-94.

[35] Muhn P, Fuhrmann U, Fritzemeier KH, Krattenmacher R, Schillinger E. Drospirenone: a novel progestogen with antimin-eralocorticoid and antiandrogenic activity. Ann N Y Acad Sci 1995;761:311-35.

[36] Fuhrmann U, Krattenmacher R, Slater EP, Fritzemeier KH. The novel progestin drospirenone and its natural counterpart progesterone: biochemical profile and antiandrogenic potential. Contraception 1996;54:243-51.

[37] Krattenmacher R. Drospirenone: pharmacology and pharmacokinetics of a unique progesterone. Contraception 2000;62: 29-38.

[38] Losert W, Casals-Stenzel J, Buse M. Progestogens with antimineralocorticoid activity. Arzneimittelforschung 1985;35: 459-71.

[39] Pollow K, Juchem M, Elger W, Jacobi N, Hoffmann G, Mobus V. Dihydrospirorenone (ZK30595): a novel synthetic progesteronecharacterization of binding to different receptor proteins. Contraception 1992;46:561-74.

[40] Rübig A. Drospirenone: a new cardiovascular-active progestin with antialdosterone and antiandrogenic properties. Climacteric 2003;6(Suppl. 3):49-55.

[41] Schurmann R, Holler T, Benda N. Estradiol and drospirenone for climacteric symptoms in postmenopausal women: a double-blind, randomized, placebo-controlled study of the safety and efficacy of three dose regimens. Climacteric 2004;7: 189-96.

[42] Warming L, Ravn P, Nielsen T, Christiansen C. Safety and efficacy of drospirenone used in a continuous combination with 17betaestradiol for prevention of postmenopausal osteoporosis. Climacteric 2004;7:103-11.

[43] Archer DF, Thorneycroft IH, Foegh M, et al. Long-term safety of drospirenone-estradiol for hormone therapy: a randomized, doubleblind, multicenter trial. Menopause 2005; 12: 716-27.

[44] Oelkers W. Drospirenone, a progesterone with antimineralocorticoid properties: a short review. Mol Cell Endocrinol 2004;217:255-61.

[45] ElgerW, BeierS, Pollow K, Garfield R, ShiSQ, HillischA. Conception and pharmacodynamic profile of drospirenone. Steroids 2003;68:891-905

[46] Kuhl H. Pharmacology of estrogens and progestogens: influence of different routes of administration. Climacteric 2005;8(Suppl. 1):3-63.

[47] Sitruk-Ware R. New progestogens. A review of their effects in perimenopausal and postmenopausal women. Drugs Aging 2004;21:865-

[48] Stanczyk FZ. Pharmacokinetics and potency of progestins used for hormone replacement therapy and contraception. Rev Endocr Metab Disord 2002;3:211-24

[49] World Health Report 2002. Reducing risks, promoting healthy life. Geneva, Switzerland: World Health Organization; 2002. Available at http://www.who.int/whr/2002/en/index.html [Accessed 6 July 2006].

[50] Kannel WB. Fifty years of Framingham Study contributions to understanding hypertension. J Hum Hypertens 2000; 14:83-90.

[51] Franklin SS, Gustin IV W, Wong ND, et al. Hemodynamic patterns of age-related changes in blood pressure. The Framingham Heart 
Published in: Maturitas (2006), vol. 55, iss.4, pp. 297-307

Status: Postprint (Author's version)

Study. Circulation 1997;96:308-15.

[52] WHO Statistical Information System (WHOSIS). World health statistics 2006. Available at http://www.who.int/ whosis/whostat2006/en/index.html [Accessed 6 July 2006].

[53] Mueck AO, Seeger H. Effect of hormone therapy on BP in nor-motensive and hypertensive postmenopausal women. Maturitas 2004;49:189-203.

[54] Preston RA, Alonso A, Panzitta D, et al. Additive effect of drospirenone/17-beta-estradiol in hypertensive postmenopausal women receiving enalapril. Am J Hypertens 2002;15:816-22.

[55] Preston RA, White WB, Pitt B, et al. Effects of drospirenone/17-beta estradiol on blood pressure and potassium balance in hypertensive postmenopausal women. Am J Hypertens 2005; 18:797-804.

[56] White WB, Pitt B, Preston RA, Hanes V. Antihypertensive effects of drospirenone with 17ß-estradiol, a novel hormone treatment in postmenopausal women with stage I hypertension. Circulation 2005;112:1979-84.

[57] Mancia G, Omboni S, Parati G, Ravogli A, Villani A, Zanchetti A. Lack of placebo effect on ambulatory blood pressure. Am J Hypertens 1995;8:311-5.

[58] Staessen JA, Wang J-G, Thijs L. Cardiovascular protection and blood pressure reduction: a meta-analysis. Lancet 2001;358:1305-15.

[59] MacMahon S. Blood pressure and the prevention of stroke. J Hypertens Suppl 1996;14:S39-46.

[60] Neal B, MacMahon S, Chapman N, Blood Pressure Lowering Treatment Trialists' Collaboration. Effects of ACE inhibitors, calcium antagonists, and other blood-pressure-lowering drugs: results of prospectively designed overviews of randomised trials. Lancet $2000 ; 356: 1955-64$

[61] Lewington S, Clarke R, Qizilbash N, et al. Prospective Studies Collaboration. Age-specific relevance of usual blood pressure to vascular mortality: a meta-analysis of individual data for one million adults in 61 prospective studies. Lancet 2002;360:1903-13.

[62] Oelkers W, Foidart JM, Dombrovicz N, et al. Effects of a new oral contraceptive containing an antimineralocorticoid progestogen, drospirenone, on the renin-aldosterone system, body weight, blood pressure, glucose tolerance, and lipid metabolism. J Clin Endocrinol Metab 1995;80:1816-21.

[63] Foidart JM, Wuttke W, Bouw GM, Gerlinger C, Heithecker R. A comparative investigation of contraceptive reliability, cycle control and tolerance of two monophasic oral contraceptives containing either drospirenone or desogestrel. Eur J Contracept Reprod Health Care 2000;5:124-34.

[64] Huber J, Foidart JM, Wuttke W, et al. Efficacy and tolerability of a monophasic oral contraceptive containing ethinylestra-diol and drospirenone. Eur J Contracept Reprod Health Care 2000;5:25-34. 